\title{
Online marketing. A ground to exploit and grow the accessing of European funds
}

\author{
Anamaria - Cătălina, RADU \\ Bucharest University of Economic Studies, Bucharest, Romania \\ anamaria_radu15@yahoo.com \\ Alexandra, PRICOP \\ Bucharest University of Economic Studies, Bucharest, Romania \\ ada.pricop@yahoo.com \\ Raluca Florentina , TITA \\ Bucharest University of Economic Studies, Bucharest, Romania \\ raluca.tita292@gmail.com \\ Mioara, POPESCU \\ Bucharest University of Economic Studies, Bucharest \\ mio.popescu@yahoo.com
}

\begin{abstract}
Accessing European funds is very controversial at this moment because of its enormous benefits for the country development. A very important aspect regarding the image of a country is represented by the tourism, and European funds offer an opportunity for raising the potential of a country by coordinating the tourism activities. Tourism planning also has a big impact its advantages being very resourceful due to a responsible funds allocation. In this paper, we have been analyzing a few European funded project - POSDRU 2007-2013 for the development regions. The future direction in developing projects in the field of tourism is to follow very carefully the objectives of the implemented projects and to plan all the activities in a balanced manner. The paper also shows how online communication can contribute to facilitate the access of the European funds and a better implementation and develop of the projects.
\end{abstract}

Keywords: European funds, regional development, online communication, marketing in tourism.

JEL Classification: M31.

\section{Introduction}

The online environment has greatly contributed to improving the strategic activity in an organisation and has facilitated people-to-people contact by 
creating the right environment for organisations to develop and deliver their products under the best conditions.

Online since its very beginning, has been an attraction to all different targets so, thinking strategic means we have to use it wisely and exploit as much we can.

Thus, it is important that the online marketing strategy draws users' attention and makes them constantly visit their website. In order for the actions conducted in the online environment to lead to the best results, it is essential to carry out the following activities (Anselmo, 2010, pp.155-156): Constantly posting new messages on blogs or social networks; Constantly updating blogs with new information; Using hyperlinks to facilitate the search for information; Posting additional links; Posting the website in relevant directories and in certain databases; Constant gathering of information from consumers through specific forms or carrying out research; Making integrated online marketing campaigns focused on customers; Providing users with the opportunity to register to get different benefits: free news, free products, etc.

Before an organisation can conclude different online strategy partnerships, it needs to carry out a series of analyses outlining the benefits it can subsequently obtain. In addition, the digital environment provides them with the opportunity to perform various analyses to track the effectiveness of the website. Subsequently, if the site is considered to be of interest to users, the company can make the decision to invest in it and to enter into an online partnership.

Establishing the marketing strategy is one of the most important steps in the planning process, illustrating how the company should operate in order to achieve its objectives (Stăncioiu et al., 2005).

At this time, we can conclude that at the ground of the economy is laying the globalisation process, the digitalisation process and also the information society development next to the online technologies progress.

In the field of accessing European funds, marketing planning is very important, it being the one that illustrates how resources should be distributed within development regions so that the results obtained following the implementation are as beneficial as possible. In addition, the online environment plays an important role, facilitating the communication with beneficiaries and enabling them to get the information they need in decision-making easier. In the next part, we analysed the way in which the European funds were distributed in 
the North-East and North-West development regions through the Regional Operational Programme.

\section{The degree of absorption of European funds registered at the level of the Regional Operational Programme - North-East development region}

According to the ministry website (www.mdrap.gov.ro) "in the North-East development region, a total of 1,643 projects were submitted by September 2015 , the requested amount being 6,871.7 million lei. Of these, 718 projects were rejected. The number of projects contracted amounted to 682 , their value reaching 3,658.3 million lei. The overall utilisation rate for this region was 169.3\%."

In order for the activity carried out in the North-East development region to have the highest impact among the targeted audience, the Regional Development Agency has developed a communication plan aimed at increasing the level of information, awareness and transparency regarding the activities of the European Union, as well as the creation of a coherent picture of the assistance provided in the development region.

"The communication plan of this region is made public and can be accessed by the entire target audience, including potential beneficiaries, 2007-2013 ROP beneficiaries, the general public, the internal public, the media. Regarding the European funds allocated in the North-East development region until 30.09.2015, it can be noticed that, under Priority Axis 5, a total of 202 projects were submitted, the requested amount being 892.2 million lei." (www.mdrap.gov.ro)

Analysing from the perspective of distribution in the key areas of intervention, it can be noticed that most of them were submitted in the field of promotion in tourism (122), 53 in the field of accommodation and catering, and 27 in the field of cultural heritage. Of the total number of projects submitted under this axis, $37.13 \%$ were rejected, most of them being registered in the field of tourism promotion (50), followed by accommodation and recreation (20) and cultural heritage (5). Until September 2015, a total of 114 projects were contracted under this axis, most of them registered in the field of tourism promotion (58.77\% of the total number of projects contracted under this axis), accommodation and recreation (21.93\%), as well as in the field of cultural heritage (19.3\%). 
"The total value of these projects was 537.2 million lei, most were developed in the field of tourism promotion, the highest requested amounts were recorded at the level of cultural heritage projects (59.19\%), accommodation and catering (32.29\%) and tourism promotion (8.51\%), the requested amount of projects under assessment and contracted in relation to the amount of financial allocations obtained in this region for the above specified axis was $111.4 \%, 5.1$ the utilisation rate was $117.9 \%$, for area 5.2 the obtained percentage was $133.3 \%$, while for the promotion of tourism the utilisation rate was $51.8 \% "$ according to the Regional Development Ministry.

Table 1 '--'Utilisation rate' of 'European funds'through'ROP'in'the'North-East'

\begin{tabular}{|c|c|c|c|c|c|c|c|c|c|}
\hline & & & & & & $M_{1}$ & & & \\
\hline \multirow{2}{*}{$\begin{array}{l}\infty \\
\infty\end{array}$} & \multirow{2}{*}{\begin{tabular}{l|} 
Priority \\
axis $\cdot / \cdot$ Key \\
area' of $\cdot$ \\
interventiona
\end{tabular}} & \multirow{2}{*}{$\begin{array}{l}\text { Amount- } \\
\text { allocated } \\
\text { (ERDF+'· } \\
\text { State' } \\
\text { Budget)a }\end{array}$} & \multicolumn{2}{|c|}{$\begin{array}{l}\text { Projects· } \\
\text { submitteda }\end{array}$} & \multicolumn{2}{|c|}{$\begin{array}{l}\text { Projects· } \\
\text { rejecteda }\end{array}$} & \multicolumn{2}{|c|}{$\begin{array}{l}\text { Projects' } \\
\text { contracted } \alpha\end{array}$} & \multirow[t]{2}{*}{$\begin{array}{l}\text { Utilisati } \\
\text { on rate }{ }^{*_{0}}\end{array}$} \\
\hline & & & No.a & $\begin{array}{l}\text { Amo } \\
\text { unt } \\
\text { reque } \\
\text { stedo } \\
\end{array}$ & \begin{tabular}{|l|}
$\mathbf{N}$ \\
0.0
\end{tabular} & $\begin{array}{l}\text { Amo } \\
\text { unt· } \\
\text { reque } \\
\text { steda }\end{array}$ & No.a & $\begin{array}{l}\text { Amo } \\
\text { unt } \\
\text { requ } \\
\text { esteda }\end{array}$ & \\
\hline \multirow[t]{4}{*}{$\begin{array}{l}\text { North-" } \\
\text { Easto. }\end{array}$} & $\begin{array}{l}\text { AXIS· } 5 \cdot \\
\text { Tourisma }\end{array}$ & 553.730 & 2020 & 892.20 & 750 & $275.5 \%$ & 1140 & 537.20 & $111.4 \%$ \\
\hline & $\begin{array}{l}\mathbf{5 . 1} \cdot{ }^{\prime} \\
\text { Cultural· } \\
\text { heritagea }\end{array}$ & 286.4000 & 270 & 353.20 & 50 & 15.50 & 220 & 318.00 & $117.9 \%$ \\
\hline & $\begin{array}{l}5.2 \cdot \\
\text { Tourist. } \\
\text { accommoda } \\
\text { tion and } \\
\text { recreationa }\end{array}$ & 172.330 & 530 & 454.30 & 200 & 224.6 & 250 & 173.50 & $133.3 \%$ \\
\hline & $\begin{array}{l}5.3 \cdot \\
\text { Tourism. } \\
\text { promotion' }\end{array}$ & 95.000 & 1220 & 84.70 & $50: 0$ & 35.40 & 670 & 45.70 & $51.8 \%$ \\
\hline
\end{tabular}

*the utilisation rate represents the requested amounts in the projects under assessment and contracted in relation to the amount of financial allocations

Source: inforegio.ro 
Regarding the "objectives pursued by the projects funded through ROP 2007-2013", we can mention the following (inforegionordest.ro):

In key area of intervention 5.2 projects aimed: to invest in a winter mountain park; to expand and modernise certain hotels, guest houses or motels in the region; to build a spa centre and a club; to arrange private parking; to create recreational areas; some centres and parks;

In key area of intervention 5.1, projects aimed: to rehabilitate historical centres, certain museums, historical monuments, fortresses, monasteries and churches, as well as theatres;

The first part of this article presents how important is to focus on the tourist that will bring profit to the image of the country but also to its economy.

\section{The degree of absorption of European funds registered at the level of the Regional Operational Programme - North-West development region}

This paper is based on all communication plans that existed at programme level during the period 2007-2013. Starting from the general aspects characterising the Regional Operational Programme, in the following we have studied the evolution of the projects under Priority axis 5 , the one targeting investments made in tourism.

According to the analyses conducted, a total of 140 projects were submitted under Priority axis 5 level in the North-West development region until September 2015. The total amount allocated to this Axis was 337.81 million lei. For the projects submitted, the requested amount was 680.3 million lei, most of which was directed towards projects aimed at improving accommodation and recreation (372.4 million lei).

Of the total projects submitted, most aimed tourism promotion (67.86\%), tourist accommodation (17.14\%) and cultural heritage (15\%). Out of all the submitted projects, $42.86 \%$ were rejected, their requested amount being 368.9 million lei. $51.43 \%$ of all projects submitted under Priority axis 5 were contracted. Most of them aimed the promotion of tourism (72.22\%), cultural heritage (16.67) and accommodation and recreation (11.11\%). The requested amount of the contracted projects was 305.9 million lei, the highest being recorded for cultural heritage (140.6 million lei), followed by tourist 
accommodation and recreation (131.9 million lei) and tourism promotion (33.4 million lei).

As far as the utilisation rate is concerned, in the Priority axis within the North-West development region it reached $92.2 \%$. In the key areas of intervention, the weights were as follows: $111.8 \%$ for cultural heritage projects, $92.8 \%$ for tourist accommodation and recreation projects and $55.3 \%$ for tourism promotion projects.

Table'2--Utilisation'rate' of European'funds 'through 'ROP'in'the'North-

\begin{tabular}{|c|c|c|c|c|c|c|c|c|c|}
\hline \multirow{2}{*}{$\frac{9 x}{9 x}$} & \multicolumn{9}{|c|}{ 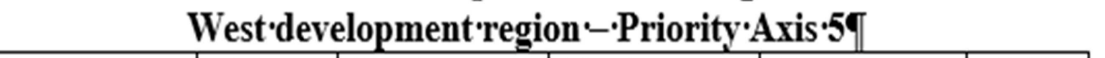 } \\
\hline & \multirow{2}{*}{\begin{tabular}{l|} 
Priority \\
axis $* / \cdot$ Key \\
area $\cdot$ of \\
interventiona
\end{tabular}} & \multirow{2}{*}{$\begin{array}{l}\text { Amoun } \\
\mathbf{t} \cdot \\
\text { allocat } \\
\text { ed· } \\
\text { (ERDF } \\
+\cdot \text { State } \\
\text { Budget } \\
\text { )a }\end{array}$} & \multicolumn{2}{|c|}{$\begin{array}{l}\text { Projects. } \\
\text { submitteda }\end{array}$} & \multicolumn{2}{|c|}{$\begin{array}{l}\text { Projects' } \\
\text { rejecteda }\end{array}$} & \multicolumn{2}{|c|}{$\begin{array}{l}\text { Projects' } \\
\text { contracted } \alpha\end{array}$} & \multirow{2}{*}{$\begin{array}{l}\text { Utilis } \\
\text { ation. } \\
\text { rate }{ }^{*} \alpha\end{array}$} \\
\hline $9 x$ & & & No.a & $\begin{array}{l}\text { Amo } \\
\text { unt } \\
\text { reque } \\
\text { stedo }\end{array}$ & No.0 & $\begin{array}{l}\text { Amo } \\
\text { unt· } \\
\text { reque } \\
\text { steda }\end{array}$ & No.ra & $\begin{array}{l}\text { Amo } \\
\text { unt· } \\
\text { requ } \\
\text { ested }\end{array}$ & \\
\hline \multirow{4}{*}{$\begin{array}{l}\text { North } \\
-\cdot \\
\text { Westo. }\end{array}$} & $\begin{array}{l}\text { AXIS' 5' - } \\
\text { Tourisma }\end{array}$ & 337.810 & $140 \%$ & 680.30 & $60 \%$ & $368.9 \%$ & $72 \alpha$ & $305.9 \mathrm{a}$ & $92.2 \%$ \\
\hline & $\begin{array}{l}5.1^{\cdot} \\
\text { Cultural· } \\
\text { heritaged }\end{array}$ & 126.920 & 210 & $247.7 x$ & 90 & $105.9 \times$ & $12 \infty$ & $140.6 \mathrm{~m}$ & $\begin{array}{l}111.8 \\
\% \infty\end{array}$ \\
\hline & $\begin{array}{l}5.2 \cdot \\
\text { Tourist } \\
\text { accommoda } \\
\text { tion } \cdot \text { and } \\
\text { recreationo }\end{array}$ & 140.780 & 240 & 372.40 & $16 \%$ & $241.7 \mathrm{a}$ & 80 & 131.90 & $92.8 \%$ \\
\hline & $\begin{array}{l}5.3 \cdot \\
\text { Tourism. } \\
\text { promotion } \alpha\end{array}$ & $70.10 x$ & 950 & 60.20 & $35 \%$ & 21.40 & 520 & $33.4 \%$ & $55.3 \%$ \\
\hline
\end{tabular}

Source: inforegio.ro

According to the analyses conducted, it has been noticed that approximately 36 cultural and historical heritage objectives (nord-vest.ro) have been improved through the 12 projects funded in the key area of intervention 5.1 (cultural heritage). Thus, 28 churches, 3 museums and historic buildings, 2 
castles, 2 Roman castra as well as a fortress were rehabilitated as a result of these projects, their beneficiaries using all the funds made available.

As previously noted, in addition to these projects, others have also been implemented under Priority axis 5, aimed at creating and improving the tourism infrastructure in the region (nord-vest.ro). Thus, they offered the possibility of further developing the spa potential in the development region, with a number of spa parks built in different destinations such as: Dej, Cojocna, Figa, Tăşnad, Beltiug and Marghita.

The 8 projects contracted and implemented in the North-West development region have used, to a high proportion, almost all the resources made available. The results obtained from these investments quickly reflected in the tourism activity in the development region, leading to an increase in the number of tourists, the length of their stay, as well as the improvement of accommodation and recreation services.

\section{Discussion, and Conclusions}

From those shown in this study, we noticed that, during the analysed period, a number of resources were allocated for the development of tourism in the North-East and North-West development regions. However, part of the projects that have been implemented have not benefited from the initial results. In order to be successful in the coming years, it is very important that the entire process of accessing European funds be planned in order to enable the balanced allocation of resources in each development region. Furthermore, certain online communication tools should be implemented to facilitate contact with consumers and improve the process of accessing and implementing European funds.

\section{References}

[1] Anselmo D. (2010). Marketing Demystified. Ist Edition. London : McGraw-Hill Education;

[2] Downes, L., Mui, C. (1998). Unleashing the Killer App: Digital Strategies for Market Dominance. Boston: Harvard Business School Press;

[3] Stăncioiu, A.-F. (coord), Caescu, S. C., Filip, A., lonescu, F.T., Constantinescu, M. (2005). Planificarea de marketing în turism : concepte și aplicații. București : Economica; 
[4] www.inforegio.ro

[5] www.inforegionordest.ro

[6] www.nord-vest.ro

[7] http://www.mdrap.gov.ro/_documente/inforegional/2009/no2_2009.pdf 